\title{
Wiedza czynnikiem poprawy konkurencyjności gospodarki w UE
}

\section{Wstęp}

Za fundamentalny potencjał we współczesnej gospodarce uznaje się wiedzę, bez której społeczeństwa nie są w stanie funkcjonować w warunkach globalizacji i powszechnej konkurencji. Wiedza staje się centralnym składnikiem produkcji, a uczenie się najważniejszym procesem gospodarczym [OECD 2000]. Jak stwierdzono, na podstawie licznych badań, zasoby oparte na wiedzy stają się w organizacjach czynnikiem dominującym. Jest to związane ze specyficznymi cechami, które ma wiedza, a których nie mają inne zasoby. Do nich można zaliczyć jej niewyczerpalność.

Poza tym dynamiczne przeobrażenia ekonomiczne, kulturalne, społeczne i naukowe występujące w życiu ludzi niosą potrzebę ciągłego aktualizowania, pogłębiania i doskonalenia wiedzy podstawowej oraz nabywania kompetencji kluczowych, ciągle ewaluujących, dostosowujących się do zmiennych warunków pracy i zmieniającego się świata. Tempo przemian sprawia, że wiedza i umiejętności są poddawane nieustannej moralnej deprecjacji, a to wymaga ciagłego uczenia się [OECD 2000]. Dzięki wzrostowi średniej długości życia wiele ludzi po przejściu na emeryturę ma możliwość dowolnego dysponowania czasem, a tym samym realizacji różnych pozazawodowych planów edukacyjnych [Delors 1998].

W tym kontekście można stwierdzić, że społeczeństwo XXI w. powinno być społeczeństwem wiedzy, uczącym się społeczeństwem, a nowa gospodar$\mathrm{ka}$, gospodarką wiedzy - knowledge-based economy [OECD 2000].

Wiedza i sposoby jej pozyskiwania znalazły się więc $w$ kręgu zainteresowań nie tylko psychologów i pedagogów, ale również ekonomistów, specjalistów od zarządzania, polityków i menedżerów, a państwa członkowskie Unii Europejskiej wprowadziły do swoich programów politycznych nowy cel, jakim jest „,uczenie się przez całe życie" [Eurydice 2000]. 


\section{Róźne koncepcje uczenia się przez całe życie}

Koncepcja uczenia się przez całe życie nie jest myślą nową zrodzoną u progu XXI wieku. Już w 1963 r. Komisja Europejska formułując cele wspólnej polityki, zwłaszcza $\mathrm{w}$ dziedzinie zatrudnienia, dostrzegała potrzebę: po pierwsze - zagwarantowania pracownikom prawa do kształcenia i szkolenia zawodowego oraz podnoszenia zdolności adaptacyjnych na zmieniającym się rynku pracy; po drugie - rozwijania systemu ustawicznego kształcenia zawodowego [Bos 2003].

Międzynarodowa Komisja ds. Rozwoju Edukacji pracująca pod kierownictwem Edgarda Faure'a - po przeprowadzeniu, na zlecenie UNESCO, międzynarodowych badań $w$ dziedzinie oświaty - przedstawiła w 1972 r. wizjonerska, a zarazem uniwersalną koncepcję uczenia się przez całe życie. W raporcie $\mathrm{z}$ tych badań zatytułowanym "Uczyć się, aby być. Świat edukacji dziś i jutro" przypomniano prawo każdego człowieka do ustawicznego kształcenia. Jednocześnie zalecono:

- zniesienie barier zamykających dostęp do nauki grupom najmniej uprzywilejowanym, a tym samym zapewnienie każdemu człowiekowi możliwości uczenia się;

-. powiązanie formalnego systemu kształcenia ${ }^{1} \mathrm{z}$ kształceniem nieformalnym $^{2}$ oraz sprawiedliwy rozdział środków między te systemy;

- uelastycznienie systemów kształcenia;

- podniesienie jakości nauczania;

- szersze uczestnictwo uczniów, studentów i shuchaczy w projektowaniu procesów kształcenia i kierowaniu nimi.

Powyższa koncepcja stała się integralnym elementem polityk krajowych i międzynarodowych. Jej uniwersalność doprowadziła jednak do pewnych niejasności i sprawiła, że brak jest dziś jednoznacznej i precyzyjnej definicji pojęcia „uczenie się przez całe życie”. Ponadto, w różnych dokumentach państw członkowskich Unii Europejskiej i innych publikacjach możemy spotkać się z następującymi określeniami: „edukacja przez całe życie”, „kształcenie przez całe życie” a nawet „kształcenie ustawiczne” i „kształcenie dorosłych”. Zwolennicy używania terminu „uczenie się przez całe życie" są zdania, że jest on nierozerwalnie związany $\mathrm{z}$ indywidualną odpowiedzialnością człowieka za wybór drogi zdobywania wiedzy i jej zakresu, zapewniającej zaspokojenie po-

\footnotetext{
${ }^{1}$ Kształcenie formalne obejmuje różne formy edukacji prowadzonej w'szkołach, ośrodkach kształcenia zawodowego, uczelniach i placówkach nauczania i uczenia się dorosłych.

${ }^{2}$ Kształcenie nieformalne odbywa się w domu, w zakładzie pracy, na wycieczce, w klubie, teatrze itd.
} 
trzeb intelektualnych oraz zdobycie umiejętności ułatwiających utrzymanie lub pozyskanie pracy. Uważają natomiast, że inne określenia kojarzą się ze sformalizowanym systemem kształcenia [Eurydice 2000].

W opracowaniu UNESCO zatytułowanym „Edukacja: jest w niej ukryty skarb" proponuje się umieścić edukację przez całe życie w centrum społeczeństwa, rozumiejąc ją jako proces obejmujący całe życie (od dzieciństwa po kres życia), umożliwiający każdej jednostce ludzkiej poznanie dynamiki świata, innych ludzi i siebie.

W przywołanej publikacji UNESCO podkreśla się, że kształcenie formalne zorientowane jest głownie na: uczyć się, aby wiedzieć i częściowo na: uczyć się, aby dziatać. Każdy natomiast $\mathrm{z}$ powyższych filarów edukacji powinien być przedmiotem jednakowej troski organizatorów kształcenia formalnego oraz osób uczących się poza systemem sformalizowanym. Takie podejście do edukacji umożliwi wszystkim ludziom odkrywanie, pobudzanie i wzmacnianie ich potencjału twórczego oraz rozwój inteligencji umysłowej i emocjonalnej, wrażliwości, poczucia estetyki, jak też osobistej odpowiedzialności i duchowości. J. Delors uważa jednak, że nie da się powyższego projektu urzeczywistnić bez odejścia od wizji edukacji instrumentalnej, podporządkowanej celom utylitarnym (nabyciu umiejętności i sprawności) oraz celom o charakterze ekonomicznym na rzecz indywidualnego rozwoju człowieka i promowania uczenia się, aby żyć wspólnie, a zwłaszcza, aby być [Delors 1998].

Zbliżone stanowisko zajmują Rada Unii Europejskiej ds. Edukacji i Komisja Europejska. Świadczy o tym treść przesłania politycznego, zawartego w raporcie, jaki wymienione instytucje przyjęły w marcu $2002 \mathrm{r}$. na posiedzeniu w Barcelonie. W raporcie tym czytamy: Edukacja jest czymś więcej niz czynnikiem dajacym szanse na zatrudnienie - przygotowujqc do pracy zawodowej przyczynia się do samorealizacji oraz ksztaltuje aktywnq postawe obywatelskq $w$ demokratycznych spoteczeństwach, $w$ których szanuje się różnorodność kulturowq $i$ językowa. Edukacja odgrywa również istotnq rolę w tworzeniu spoleczeństwa zintegrowanego, zapobiegajac dyskryminacji, marginalizacji, rasizmowi $i$ ksenofobii, a takize promujqc takie fundamentalne wartości wyznawane przez spoteczeństwa europejskie, jak tolerancja i poszanowanie praw czlowieka. W epoce wiedzy $i$ globalizacji tworzenie spójnego wewnętrznego $i$ otwartego europejskiego obszaru edukacyjnego będzie mialo zasadnicze znaczenie dla przyszłości Europy $i$ jej obywateli [Edukacja w Europie... 2003].

$\mathrm{Z}$ kolei koncepcja uczenia się przez całe życie sformułowana przez OECD, w odróżnieniu od koncepcji UNESCO, zorientowana jest głównie na program konkretnych działań, na rozwój życia zawodowego. Podkreśla się w niej potrzebę objęcia kształceniem zarówno dzieci i młodzieży, jak też osób dorosłych, 
które muszą zmienić zawód lub podnieść swoje kwalifikacje. Kształcenie to powinno zmierzać do rozwoju różnych umiejętności i sprawności niezbędnych w życiu zawodowym, rodzinnym i społecznym - zarówno w systemie szkolnym, jak i pozaszkolnym. Proponuje się jednocześnie cały system standardów wiedzy i umiejętności, które powinny być opanowane przez uczących się, niezależnie od wieku. Projekt ten zakłada partnerską współpracę władzy publicznej, instytucji i samych kształconych, z tym że większą odpowiedzialność za prowadzenie, zarządzanie i finansowanie oświaty przypisuje się sektorowi prywatnemu i samym uczniom (słuchaczom) [Eurydice 2000].

Ponadto, zdaniem OECD, koncepcja uczenia się przez całe życie wymaga, aby szkoła wdrożyła swoich wychowanków do ciagłego kształcenia się, do zdobywania różnych umiejętności. Chodzi głównie o to, aby absolwenci potrafili:

- określać własne potrzeby edukacyjne i sposoby ich zaspokajania;

- dostosować własny styl operowania wiedza, myślenia, samokontroli

- i samoregulacji do strategii uczenia się;

- samodzielnie uczyć się w różnym kontekście, innym niż kształcenie formalne (praca, rozrywka, dom itp.);

- poszukiwać i selekcjonować informacje oraz kreować wiedzę [OECD 2000].

Eksplozja zainteresowań koncepcją uczenia się przez całe życie, zwłaszcza przez Unię Europejska, nastąpiła w latach 90. Wskazują na to następujące opracowania poruszające analizowany problem:

1. „Memorandum w sprawie szkolnictwa wyższego we Wspólnocie Europejskiej" (Memorandum on Higher Education in the European Community) (1991 r.). W dokumencie tym przedstawiono istotny wkład szkół wyższych w tworzenie Jednolitego Rynku. Podkreślono jednocześnie potrzebę znacznego rozszerzenia dostępu młodzieży do tych szkół oraz umożliwienia pracującym dokształcania się i doskonalenia na poziomie wyższym.

2. „Memorandum w. sprawie kształcenia otwartego i na odległość we Wspólnocie Europejskiej" (Memorandum on Open Distance Learning in the European Community) (1991 r.). Wykazano w nim, że kształcenie otwarte i na odległość jest waźnym instrumentem pozwalającym rozszerzyć dostęp do kształcenia ogólnego i zawodowego przez całe życie, tym samym zaś złagodzić, a nawet (jak to określono później) rozwiąać problemy konkurencyjności, zatrudnienia i rozwoju gospodarczego [Eurydice 2000].

3. Traktat z Maastricht (1993.r.). Dokument ten stał się wyznacznikiem nowej roli Wspólnoty Europejskiej w zakresie kształcenia zawodowego. W dokumencie tym uwypuklono znaczenie kształcenia zawodowego, w tym kształcenia ustawicznego. Odpowiedzialnością za treści i organiza- 
cję kształcenia zawodowego traktat obarczył kraje członkowskie, Komisja Europejska ma tylko wspierać i uzupełniać ich działania [Bos 2003].

4. Biała Księga pt. „Nauczanie i uczenie się - ku uczącemu się społeczeństwu" (Teaching and Learning - Towards the learning society) (1995 r.). W pracy tej stwierdzono, że za proces uczenia sie przez cate życie odpowiada przede wszystkim sama jednostka. Ponadto zaproponowano, by uczenie sie przez cate życie dotyczyło w tym samym stopniu potrzeb samorealizacji i możliwości korzystania z praw obywatelskich, co osiagania celów gospodarczych. Propozycja ta uzyskała akceptację Parlamentu Europejskiego i Rady Unii Europejskiej.

5. Traktat Amsterdamski (2000 r.). Wprowadzono w nim zapis, że uczenie sie przez całe życie stanowić będzie od tej pory naczelną zasadę polityki Wspólnoty w dziedzinie edukacji i dodatkowy element polityki zatrudnienia i innych polityk [Eurydice 2000].

6. Nowe założenia do strategii zatrudnienia, reform gospodarczych oraz działań na rzecz spójności społecznej, przyjęte na szczycie w Lizbonie (2000 r.), zwane strategią lizbońską. Podstawowemu przesłaniu tej strategii nadano następujące brzmienie: Gospodarka europejska powinna stać się najbardziej konkurencyjnq $i$ dynamiczna gospodarka oparta na wiedzy, gospodarkq zdolnq do trwatego wzrostu, tworzqca coraz większq liczbe lepszych miejsc pracy $i$ zapewniajaca większa spójność spolecznq. [Edukacja w Europie... 2003].

\section{Podstawowe założenia strategii lizbońskiej i wynikające $z$ niej postanowienia}

Po szczycie w Lizbonie Komisja Europejska opracowała Memorandum, w którym pojęcie kształcenie przez całe życie zdefiniowano następująco: jest to każda forma uczenia sie, podejmowana w jakimkolwiek momencie życia $w$ celu wzbogacenia wiedzy, podniesienia kompetencji lub kwalifikacji zawodowych, obywatelskich lub społecznych. Definicja ta ma charakter ogólny i dość abstrakcyjny, ponieważ tylko w ten sposób można było oddać specyficzne warunki występujące w poszczególnych krajach. Powyższy dokument zawiera również propozycje celów dla Europy w dziedzinie edukacji (zdefiniowano trzy cele), koncentrujących się na wspólnych problemach, przy poszanowaniu odmienności poszczególnych krajów [Bos 2003].

W lutym 2002 r. w Barcelonie Rada Europejska uszczegółowiła strategię lizbońska, w tym podstawowe cele strategiczne. Przyjęto dokument pt. „Edu- 
kacja w Europie: różne systemy kształcenia i szkolenia - wspólne cele do roku 2010. Program prac dotyczący przyszłych celów systemów edukacji". (Education and training in Europe: diverse systems, shared goals for 2010.) Opracowanie to uwzględnia wszystkie systemy edukacji (od szkolnictwa podstawowego po szkolnictwo wyższe), ze szczególnym zwróceniem uwagi na kształcenie ustawiczne. Określa rọ́wnież najważniejsze środḳi i metody, które służyć będą stymulowaniu i mierzeniu postępu edukacyjnego w poszczególnych krajach oraz porównywaniu osiągnięć UE zarówno w perspektywie europejskiej, jak i ogólnoświatowej [Edukacja w Europie... 2003].

W „Programie barcelońskim” cele strategiczne zostały rozpisane na 13 celów szczegółowych i 42 zagadnienia kluczowe, wskazujące, jakie działania należy podjać, aby osiagnąć projektowane zamierzenia.

Biorąc pod uwagę analizowạną koncepcję uczenia się przez całe życie, na uwage zasługują następujące cele szczegółowe i przynależne im kluczowe zagadnienia.

Cel strategiczny 1 :

\section{Poprawa jakości i efektywności systemów edukacji w Unii Europejskiej}

Cele szzczegółowe:

1.1. Podniesienie jakości kształcenia i doskonalenia zawodowego nauczycieli i osób prowadzących szkolenia.

Sformułowano następujące działania, jakie należy podjąć w tym zakresie:

- określić umiejętności, jakie powinni posiadać nauczyciele i osoby prowadzące szkolenia zgodnie $\mathrm{z}$ ich zmieniającą się rolą $\mathrm{w}$ społeczeństwie wiedzy;

- stworzyć warunki, które ułatwią nauczycielom i osobom prowadzącym szkolenia wypełnienie zadań, jakie stawia prżed nimi społeczeństwo wiedzy;

- pozyskać do procesu nauczania i szkolenia osoby, które uzyskały doświadczenie zawodowe w innych dziedzinach.

1.2. Rozwijanie kompetencji i umiejętności potrzebnych dla społeczeństwa wiedzy.

Zalecono rozwijanie zarówno umiejętności podstawowych (liczenia, czytania, pisania itd.) i uczenia się, jak również kompetencji społecznych, koncepcyjnych, a także w dziedzinie nauk ścisłych, języków obcych i w zakresie wykorzystywania technologii informacyjno-komunikacyjnych oraz tzw. kultury ogólnej.

1.3. Zapewnienie powszechnego dostępu do technologii informacyjnb-komunikacyjnych na wszystkich poziomach kształcenia oraz do doradztwa i odpowiedniego wsparcia dydaktycznego i menedżerskiego. 
1.4. Zwiększenie rekrutacji w dziedzinie nauk ścisłych i technicznych.

1.5. Optymalne wykorzystanie zasobów.

Wdrożenie koncepcji uczenie się przez całe życie wymaga:

- znacznego zwiększenia rocznych wydatków na kapitał ludzki w przeliczeniu na jednego mieszkańca, $\mathrm{z}$ jednoczesnym zapewnieniem sprawiedliwego i efektywnego rozdziału dostępnych środków w celu ułatwienia powszechnego dostępu do edukacji i podniesienia jakości kształcenia;

- wykorzystania i rozszerzenia możliwości, jakie stwarza współpraca sektora publicznego i prywatnego.

Cel strategiczny 2:

\section{Ulatwienie powszechnego dostępu do systemów edukacji}

Cele szczegółowe:

2.1. Tworzenie otwartego środowiska edukacyjnego, zapewniającego łatwy i szeroki dostęp do wiedzy, drożność na wszystkich etapach kształcenia, zmianę kierunku zainteresowań oraz możliwość wykorzystania kwalifikacji zdobytych w swoich krajach w całej Unii Europejskiej.

$\mathrm{Z}$ celu tego wyłania się potrzeba podjęcia następujących działań:

- rozszerzenie dostępu do ofert edukacyjnych umożliwiających kształcenie ustawiczne, poprzez informacje, doradztwo oraz poradnictwo w tym zakresie;

- umożliwienie osobom dorosłym efektywnego łączenia nauki z innymi zajęciami i obowiązkami;

- promowanie różnorodnych ścieżek kształcenia;

- zachęcanie do tworzenia sieci instytucji umożliwiających uczenie się przez całe życie.

2.2. Uatrakcyjnienie procesu kształcenia i dostosowanie oferty edukacyjnej do potrzeb jednostki.

Do tego celu przypisano następujące działania kluczowe:

- inspirowanie młodzieży do kontynuowania nauki po ukończeniu obowiązku szkolnego;

- zachęcanie osób dorosłych do ciagłego kształcenia i stwarzanie im odpowiednich ku temu warunków;

- opracowanie i doskonalenie procedur oficjalnego uznawania uczestnictwa w różnych strukturach systemu kształcenia nieformalnego;

- odkrywanie i sprawdzanie różnych sposobów uatrakcyjniania nauki zarówno w obrębie systemów kształcenia formalnego, jak i nieformalnego;

- promowanie kultury uczenia się oraz rozwijanie świadomości dotyczącej korzyści społecznych i materialnych wynikających z kształcenia. 
2.3. Wspieranie aktywności obywatelskiej, zapewnienie równości szans i spójności społecznej.

Rozwinięta gospodarka wymaga osiągnięcia najwyższego poziomu kwalifikacji przez znaczną część społeczeństwa. Tylko to może zapewnić konkurencyjność na rynku towarów i usług. Przed edukacją stoi więc zadanie:

- promowania wartości i zasad demokratycznych w celu przygotowania obywateli do aktywnego udziału w życiu społecznym;

- tworzenia warunków do wyrównywania szans w ramach systemu edukacji;

- zapewnienia osobom mniej uprzywilejowanym równego dostępu do wszystkich etapów kształcenia i rozbudzanie w nich motywacji do nauki.

Cel strategiczny 3 :

\section{Otwarcie systemów edukacji na środowisko i świat}

Cele szczegółowe:

3.1. Wzmocnienie powiązań ze światem pracy, działalnością badawczą i społeczeństwem.

Realizacja tego celu wymaga:

- promowania współpracy szkół z instytucjami i organizacjami sektora biznesu, placówkami badawczymi, partnerami społecznymi i szeroko rozumianym środowiskiem lokalnym;

- przekształcenia szkół i placówek edukacyjnych w tzw. organizacje uczące się, otwarte na zmiany, różnorodne koncepcje i sugestie klientów zewnętrznych i wewnętrznych;

- zachęcania instytucji i osób indywidualnych do udziału w pracach nad rozwojem kształcenia i doskonalenia zawodowego.

3.2. Rozwijanie przedsiębiorczości.

Powinno się to odbywać poprzez:

- promowanie inicjatywy i kreatywności w miejscu pracy;

- kształtowanie umiejętności niezbędnych do założenia i prowadzenia własnej firmy.

3.3. Poprawa sytuacji w zakresie nauki języków obcych.

Zintensyfikowanie nauki języków obcych wymaga podjęcia następujących działań:

- uświadomienia potrzeby nauki języków obcych w każdym wieku;

- zachęcania szkół i innych placówek edukacyjnych do stosowania efektywnych metod nauczania języków.

3.4. Rozwijanie mobilności i wymiany.

Założono podjęcie prac zmierzających do: 
- zapewnienia osobom indywidualnym moźliwości wyjazdu za granicę, co wymaga likwidowania wszelkich barier ograniczających mobilność;

- rozpowszechnienia informacji o edukacji na całym świecie, między innymi wśród studentów, nauczycieli akademickich i pracowników naukowych.

3.5. Wzmocnienie współpracy europejskiej.

Nie da się tego celu osiagnąć bez:

- podniesienia efektywności procedur uznawania kwalifikacji oraz zapewnienia terminowego rozpatrywania wniosków o dalsze kształcenie, szkolenie i wykonywanie pracy zawodowej na terenie całej Europy;

- promowania współpracy między organizacjami i władzami odpowiedzialnymi za uznawanie kwalifikacji w celu zwiększenia kompatybilności systemów zapewniania jakości i akredytacji;

- zwiększenia przejrzystości informacji o moźliwości kształcenia w poszczególnych krajach celem stworzenia otwartego europejskiego obszaru edukacji.

Zaprezentowane działania muszą być podjęte zarówno na szczeblu Komisji Europejskiej, jak też w poszczególnych państwach członkowskich UE i pozostałych krajach należących do europejskiego systemu gospodarczego. Komisja Europejska wraz z Radą ds. Edukacji zajmą się koordynacją i monitorowaniem zintegrowanej strategii edukacyjnej, natomiast odpowiedzialność za osiagnięcie wspólnych celów spoczywać będzie na krajach uczestniczących w „Programie" [Edukacja w Europie... 2003].

W sprawie odpowiedzialności za realizacje strategii.uczenia się przez cale życie Komisja Europejska zajęła następujące stanowisko:

1. Za rozwój i realizację tej strategii odpowiedzialne są administracje poszczególnych krajów.

2. Za podnoszenie kwalifikacji zawodowych pracowników są odpowiedzialni przede wszystkim pracodawcy.

3. Organizacje związkowe powinny zabiegać o intensyfikację szkoleń i objęcie nimi wszystkich pracowników.

4. Partnerzy społeczni powinni dążyć do zawierania porozumień dotyczących kształcenia zawodowego [Bos 2003].

W 2003 r. opracowano 10 Głównych Wytycznych Europejskiej Strategii Zatrudnienia. Jedna $\mathrm{z}$ nich zaleca promować rozwój kapitału ludzkiego oraz edukację i kształcenie przez całe życie. 


\section{Uwagi końcowe}

Koncepcja uczenia się przez całe życie zakłada intensyfikację działań zmierzających do objęcia powszechną edukacją ludzi w różnym wiekù, umożliwiając im dostęp do różnych poziomów i form kształcenia. Takie całościowe podejście do nauczania i uczenia się, promujące inwestycję w kapitał ludzki, postrzegane jest w wielu krajach jako klucz do większej konkurencyjności gospodarki, lepszego wykorzystania jej zasobów, a tym samym do wzrostu dochodu narodowego.

W ostatnim ćwierćwieczu dwa ostatnie elementy powyższego modelu nabrały szczególnego znaczenia i przechodzą okres intensywnego rozwoju, zwłaszcza w krajach Europy Zachodniej. W Polsce kształcenie dorosłych ciagle nie nadazza za potrzebami. Szczególnie jest to widoczne na obszarach wiejskich, gdzie wykształcenie rolników i pozostałej ludności jest na bardzo niskim poziomie. Według Narodowego Spisu Powszechnego, w 2002 r. wykształcenie wyższe miało tylko 4,3\% mieszkańców wsi, a średnie i policealne - 22,4\% (GUS 2003). Ponadto, istnieją dość istotne różnice między formalnym poziomem uzyskanego wyksżtałcenia a rzeczywistymi umiejętnościami. Potwierdziły to wyniki badania przeprowadzonego w połowie lat 90 . pod auspicjami OECD.

Wobec powyższego, konieczne jest podjęcie działań zmierzających do poprawy jakości nauczania, modernizacji kształcenia zawodowego w kierunku dostosowania zawodów i specjalności do przemian na polskim i europejskim rynku pracy, a przede wszystkim do intensyfikacji edukacji dorosłych $\mathrm{w}$ formach szkolnych i pozaszkolnych.

\section{Literatura}

BOS D., 2003: Analiza zaleceń Komisji Europejskiej w obszarze ustawicznego ksztąłcenia zawodowego. W: Krajowy system szkolenia zawodowego. Cz. I. Wyd. Ministerstwo Gospodarki, Pracy i Polityki Społecznej, Warszawa.

DELORS J., 1998: Edukacja. Jest w niej ukryty skarb. Wyd. Stowarzyszenie Oświatowców Polskich i UNESCO, Warszawa.

EURYDICE, 2002: Uczenie się przez całe życie: rola systemów edukacji w państwach członkowskich Unii Europejskiej. Wyd. Fundacja Rozwoju Systemów Edukacji, Warszawa.

EDUKACJA W EUROPIE, 2003: Różne systemy kształcenia i szkolenia - wspólne cele do roku 2010. Program prac dotyczący przyszłych celów systemów edukacji. Wyd. Fundacja Rozwoju Systemów Edukacji, Warszawa.

OECD, 2000: Zarządzanie wiedzą w społeczeństwie uczącym się. Wydawnictwo i Zakład Poligrafii Instytutu Technologii Eksploatacji, Radom. 


\section{The Knowledge as a Factor of Competitiveness Improvement in UE Economy}

\section{Abstract}

The article presents the role of the knowledge in an economy, concepts of learning all life through and basic assumption of Lisbon strategy. It assumes that European economy, by being based on knowledge, will become more competitive and dynamic. Therefore an attention is paid to strategic targets and tasks, which refer to continuous learning. Above all they need the following:

1) quality and effectiveness improvement of education in all UE countries,

2) facilitation of public access to different educational systems,

3) opening the education on the environment and on the world.

The article emphasises different factors' responsibility for realisation of the learning all life through strategy. 
